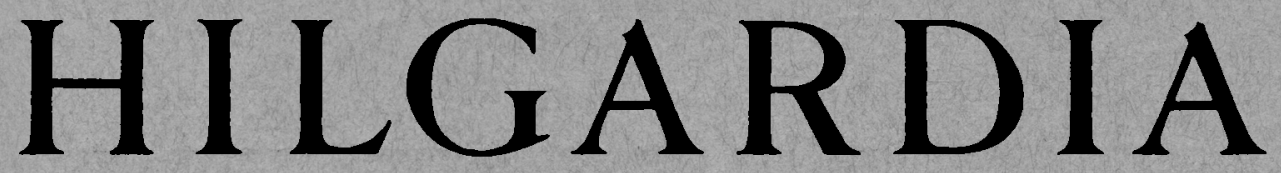

A Journal of Agricultural Science Publisbed by the California Agricultural Experiment Station

\title{
EFFECTS OF PLOT SIZE, PLOT SHAPE, AND NUMBER OF REPLICATIONS ON THE EFFICIENCY OF BEAN YIELD TRIALS
}

\author{
FRANCIS L. SMITH
}




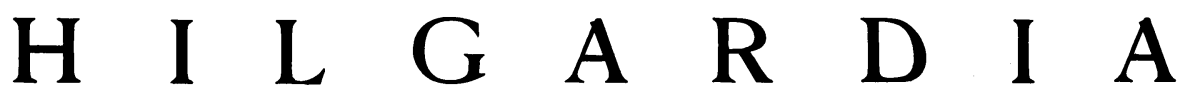

A Journal of Agricultural Science Published by

the California Agricultural Experiment Station

VCL. 28

NOVEMBER, 1958

No. 2

\section{EFFECTS OF PLOt SIZE, PLOt SHAPE, AND NUMBER OF REPLICATIONS ON THE EFFICIENCY OF BEAN YIELD TRIALS}

\author{
FRANCIS L. SMITH ${ }^{2}$
}

\section{INTRODUCTION}

Two TYPES of yield trials are conducted on beans in California, one at the experiment station, the other in counties under the direction of extension service personnel. In the experiment station, care must be taken to maintain genetic purity since the plots serve as the source of seed for the following year. In yield trials the guard rows are not harvested. Most of the work of harvesting the plots at the experiment station is done by hand. The ideal therefore would be plots as small as possible. In the county tests, the introduction of mixtures in harvesting is not so important because the beans are discarded when weighed. Since the county officers are limited in the time they can put into plot tests, the ideal plots would be those which could be planted, cultivated, irrigated, and harvested with commercial equipment. Under these conditions the number of plots rather than their size is the most important factor. Under conditions at both sites, however, the experimental plans should be adequate to obtain least significant differences of 200 pounds per acre. Bean farmers think that a difference of this magnitude has practical significance. It is therefore a worthwhile objective to obtain experimental results precise enough for statistical significance at this level.

\section{REVIEW OF LITERATURE}

Numerous experiments have been performed to get information on size and shape of experimental plots. Love $(1943)^{3}$ has pointed out that plot size depends to a large extent on the nature of the crop ; hence the experimental samples must include a number of plants. With wheat, Day (1920) found a decrease in plot variability by increasing plot size by adding to either width or length. Loessell (1936) studied a field of pea beans in which he harvested 1,890 single-row plots 10 feet long. Then he compared the variability of

\footnotetext{
${ }^{1}$ Submitted for publication November 11, 1957.

${ }^{2}$ Professor of Agronomy and Agronomist in the Experiment Station, Davis.

"See "Literature Cited" for citations referred to in the text by author and date.
} 


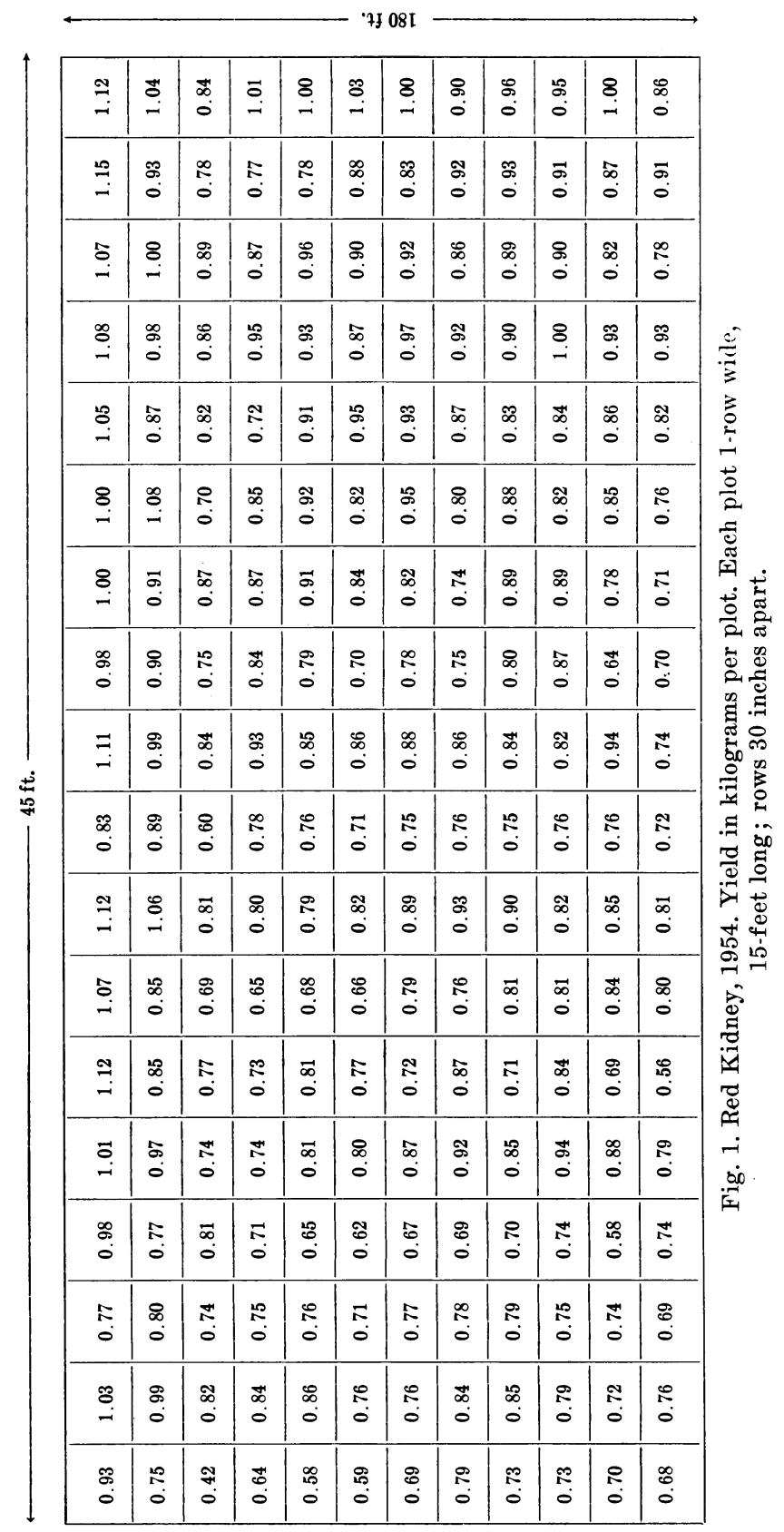




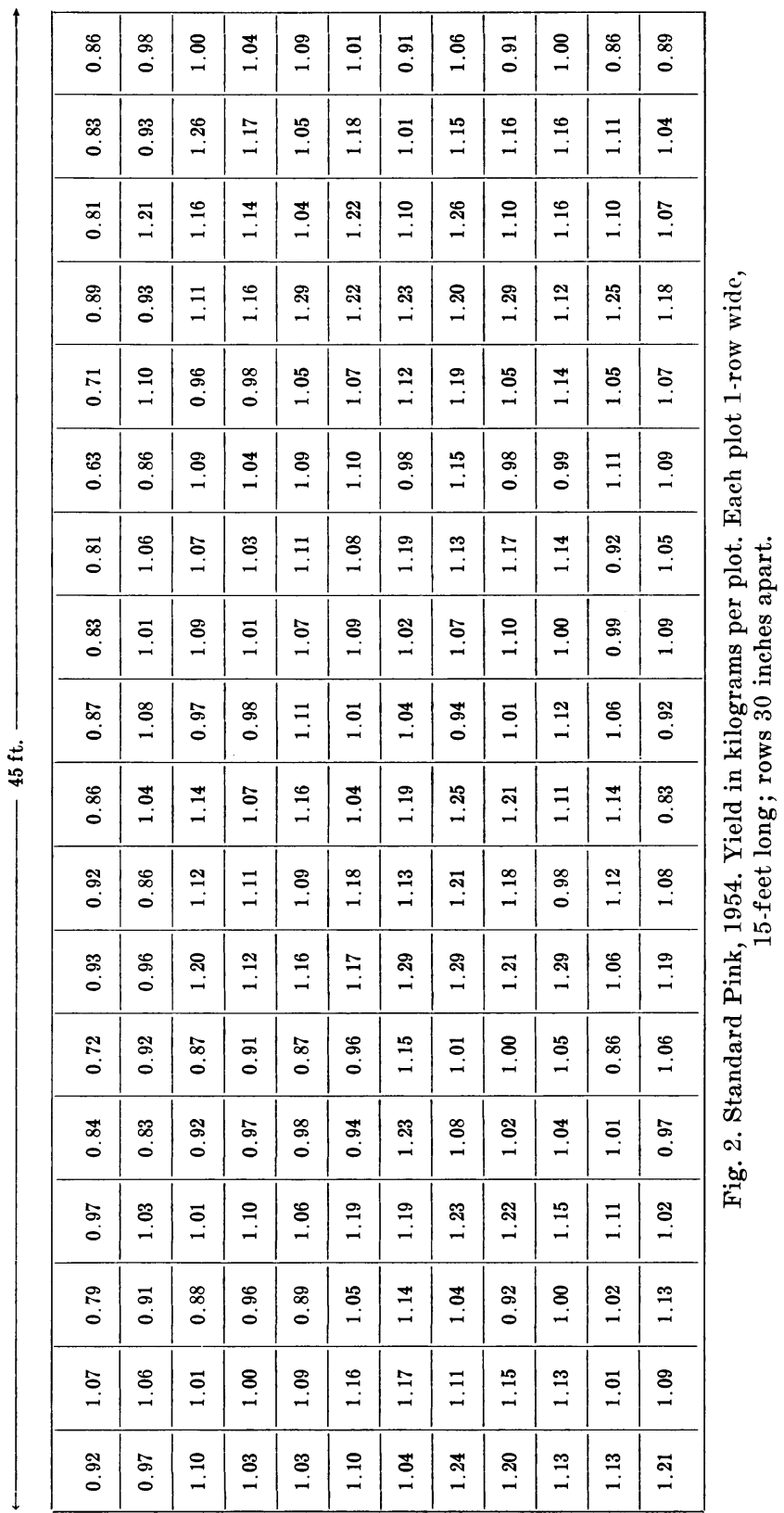


plots 1-, 2-, 3-, 4-, 6-, 9-, and 18-rows wide and 10-, 20-, 30-, 40-, and 50-feet long. The standard error decreased with length of the plots, the greatest reduction occurring between 10 and 20 feet. Further reduction was obtained at 30 feet but when the length was increased from 40 to 50 feet the reduction of the standard error did not compensate for the increase in the land used. A decrease was obtained by increasing the plot width from 1 to 2 rows. Threerow plots were only slightly better than 2-row plots. Further increases in plot width did very little in decreasing the standard errors. Loessell also studied 3-, 4-, 5-, 6-, and 9-row plots in which the outside rows were discarded as guard rows. In these plot arrangements small decreases were obtained between 3-, 4-, and 5-row plots and very little beyond that. In length, decreases were obtained between 10 and 40 feet but very little beyond. He concluded from the 108 plot sizes and shapes studied that a single-row plot 30) feet long replicated 4 times provided the most efficient use of land.

In experimental plots the soil variability found is applicable only to the area involved in the experiment. The average variability of a much larger area may or may not apply to a particular part of the field. Baker and Baker (1953) studied uniformity in 2 strawberry fields. They imposed "varieties" assigned at random to the elementary plots. Conventional $F$ values were calculated from the variance. Their study indicated that much better results were obtained if the primary plots were taken across rows rather than down rows.

Down and Thayer (1942) studied the border effect in navy bean plots and found that the border rows of high-yielding treatments were increased but not enough to equalize the loss in adjacent low-yielding plots. The center row of a 3-row plot was as efficient as the 3 center rows of a 5-row plot in minimizing border effects. Border effect did not extend more than one row.

\section{MATERIAL AND METHODS}

In 1954 two uniform plantings were made. One was Red Kidney, a bush variety, the other was Standard Pink, a viny variety. At harvest time a block of 18 rows excluding border rows was harvested in single-row plots 15-feet long. Twelve sections were taken in each row, making 216 primary plots for each variety. The yields of these primary plots are shown in figure 1 for Red Kidney and figure 2 for Pink. By adding adjacent plots a number of different plot sizes and shapes were attained. For testing 4 replications, of any plot size in shape, a block 4-plots wide and 4-plots long was taken as a unit. Four arbitrary "varieties," A, B, C, and D were assigned positions at random in each replication so that each variety had 4 replications. On these 16-plot units, analyses of variance were calculated with 3 degrees of freedom each for replications and varieties. In the smaller plot sizes a number of analyses were made from different parts of the experimental field. In very large plots the number of varieties assigned was reduced to 3 or 2 . Six replications were taken from 24 contiguous plots 4-plots wide and 6-plots long, 8 replications from 32 plots 4-plots wide and 8-plots long, and 12 replications from 48 plots 4 -plots wide and 12-plots long. The purpose of this study was to find the most efficient method of reducing experimental errors in yield trials. 
The error mean square from the analysis of variance was taken as the measure of the efficiency of a given plot design or plot size. From this term, the least significant difference (LSD) at the 5 per cent level was calculated to pounds per acre. This study was not concerned with distinguishing differences between yields of varieties. The recent criticism of using LSD's to test significance of variety means (Snedecor, 1956) is of remote concern in this study.

The experiments were repeated in 1955 . The primary plots were four times as large as in $1954-2$ rows $\times 30$ feet. The harvested area in each variety was 16-plots wide and 15-sections long, making 240 primary plots of each variety. The experimental layout and the yields of the primary plots for Red Kidney and Pink plots in 1955 are shown in figures 3 and 4 . The statistical constants of the four sets of plots were as follows:

\section{RESULTS}

\begin{tabular}{c|c|c|c|c|c|c}
\hline \hline Variety & Year & $\begin{array}{c}\text { Size of } \\
\text { primary } \\
\text { plots }\end{array}$ & $\begin{array}{c}\text { Number } \\
\text { of plots }\end{array}$ & $\begin{array}{c}\text { Mean yield } \\
\text { lbs/acre }\end{array}$ & $\begin{array}{c}\text { Standard } \\
\text { deviation, } \\
\text { lbs/acre }\end{array}$ & $\begin{array}{c}\text { Coefficient } \\
\text { of variation, } \\
\text { per cent }\end{array}$ \\
\hline Red Kidney $\ldots \ldots \ldots \ldots \ldots \ldots \ldots \ldots$ & 1954 & $1 \times 15$ & 216 & 2,134 & 302 & 14.2 \\
Standard Pink $\ldots \ldots \ldots \ldots \ldots \ldots \ldots$ & 1954 & $1 \times 15$ & 216 & 2,797 & 269 & 9.6 \\
Red Kidney ..................... & 1955 & $2 \times 30$ & 240 & 1,989 & 304 & 15.3 \\
Standard Pink................ & 1955 & $2 \times 30$ & 240 & 2,299 & 228 & 9.9 \\
\hline
\end{tabular}

\section{Red Kidney, 1954}

The least significant differences are shown for the Red Kidney data in table 1. There were 18 plot sizes with 4 replications and 10 with 6 . The average LSD for 4 replications was 259 pounds per acre and for 6 replications, 192 pounds.

From the 1954 Red Kidney plots, 174 least significant differences were calculated. The smallest plot size was 37.5 square feet. By increasing width and length of plots it was possible to get some plots as large as 900 square feet with 4 replications. The distributions of LSD values for 4 and 6 replications are shown in figure 5, and for 8 and 12 replications in figure 6. From these data, regression lines were calculated by the method of least squares. In table 1 the regression per unit area is given for plots of various widths. These calculations show that increasing plot sizes by increasing the lengths was effective in 1-, 2-, 4-, and 6-row plots but not in the 8-row plots. The behavior for the 8-row plots is shown also in figures 5 and 6 . The regression for all plots with 4 replications was only -0.43 pound per unit area. This is largely due to the 8-row plots which were exceptionally high at all levels. See table 1 and figure 5. Since the 8-row plots were the largest they were effective in keeping the regression line almost horizontal.

With 6 replications the regression decreased with increase of plot length in all plot widths except the 8-row plots. The regression of all plots with 6 replications was -4.04 per unit area. With 8 and 12 replications only one $8 \times 15$ plot was possible but the effect of the wide 8 -row plots can be seen in figure 6 . The regression coefficients were -8.36 pounds per unit area for 8 replications and -6.22 pounds for 12 replications. The average LSD for all 


\begin{tabular}{|c|c|c|c|c|c|c|c|c|c|c|c|c|c|c|}
\hline$\stackrel{\Xi}{\infty}$ & $\begin{array}{l}\text { \&ి } \\
\text { ஸे }\end{array}$ & $\begin{array}{l}\text { சे } \\
\text { i }\end{array}$ & $\stackrel{20}{\circ}$ & $\stackrel{9}{\underset{+}{*}}$ & & Tิ & \& & $\begin{array}{l}\infty \\
\dot{0} \\
\text { i }\end{array}$ & $\begin{array}{l}\text { ন্ } \\
\text { H }\end{array}$ & $\begin{array}{l}\text { Fे } \\
\text { के }\end{array}$ & $\stackrel{0}{\infty}$ & $\begin{array}{l}\text { న్లా } \\
\text { iे }\end{array}$ & $\begin{array}{l}\text { \& } \\
\text { in }\end{array}$ & $\stackrel{9}{\stackrel{9}{\infty}}$ \\
\hline $\begin{array}{l}\infty \\
\infty \\
\sim \\
\sim\end{array}$ & స్ & $\begin{array}{l}\stackrel{\infty}{\infty} \\
\infty\end{array}$ & $\begin{array}{l}\infty \\
\infty \\
\infty\end{array}$ & 范 & so & $\begin{array}{l}8 \\
\text { ஸे }\end{array}$ & $\begin{array}{l}\text { Dे } \\
\text { ஸे }\end{array}$ & ๙ึ. & $\begin{array}{c}\infty \\
\text { के }\end{array}$ & $\underset{\infty}{\sigma}$ & $\overrightarrow{\vec{n}}$ & $\begin{array}{l}\mathscr{\infty} \\
\text { ஸे }\end{array}$ & $\begin{array}{l}\infty \\
\text { ஸे } \\
\text { in }\end{array}$ & $\begin{array}{l}\text { if } \\
\text { is }\end{array}$ \\
\hline ; & $\begin{array}{l}\infty \\
\infty \\
\text { ஸ }\end{array}$ & $\overrightarrow{\text { in }}$ & $\begin{array}{l}\text { Jे } \\
\text { in }\end{array}$ & $\begin{array}{l}\infty \\
\text { m. } \\
\text {. }\end{array}$ & $\begin{array}{l}\text { ? } \\
\text { i }\end{array}$ & 8 & $\begin{array}{l}\text { م0. } \\
\text { in }\end{array}$ & $\begin{array}{l}\text { ⿵్ } \\
\text { ๓ా }\end{array}$ & $\begin{array}{l}\text { Oै } \\
\text { iे }\end{array}$ & $\stackrel{\text { I. }}{\text { is }}$ & $\begin{array}{l}\text { P్ల } \\
\text { ๙ }\end{array}$ & $\underset{\sim}{*}$ & $\begin{array}{l}\infty \\
\stackrel{\infty}{0} \\
\text { i }\end{array}$ & $\begin{array}{l}\Re \\
\stackrel{N}{N}\end{array}$ \\
\hline$\stackrel{20}{2 .}$ & $\begin{array}{l}\text { in } \\
\text { oi }\end{array}$ & $\underset{\infty}{\mathscr{8}}$ & $\begin{array}{l}\text { Fे } \\
\text { ஸे }\end{array}$ & $\begin{array}{l}\text { సี } \\
\text { ๓ }\end{array}$ & $\begin{array}{l}\bar{\sigma} . \\
\text { in }\end{array}$ & के & $\begin{array}{l}\text { 尺ి } \\
\text { ๓ }\end{array}$ & $\begin{array}{l}\vec{\infty} \\
\text { i }\end{array}$ & $\stackrel{\Re}{\dddot{m}}$ & $\begin{array}{l}20 \\
\text { N }\end{array}$ & $\underset{\sim}{\stackrel{⿰}{*}}$ & $\begin{array}{l}\text { P్ల } \\
\text { ণ }\end{array}$ & $\begin{array}{l}\text { \& } \\
\text { o }\end{array}$ & $\begin{array}{l}\infty \\
0 \\
\sim\end{array}$ \\
\hline 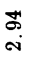 & $\underset{\sim}{\stackrel{N}{*}}$ & $\begin{array}{l}\text { ஜ } \\
\text { i }\end{array}$ & $\begin{array}{l}\text { สี } \\
\text { ๓ }\end{array}$ & $\vec{F}$ & $\begin{array}{l}\stackrel{\Re}{\text { r }} \\
\dot{0}\end{array}$ & $\begin{array}{l}8 \\
\text { \& }\end{array}$ & $\begin{array}{l}\infty \\
\infty \\
\text { i }\end{array}$ & $\begin{array}{l}\text { ชู } \\
\text { ஸ் }\end{array}$ & $\begin{array}{l}\text { ले } \\
\text { iे }\end{array}$ & $\begin{array}{l}8 \\
\text { i }\end{array}$ & $\underset{N}{N}$ & î & $\begin{array}{l}\text { P } \\
\text { o }\end{array}$ & $\stackrel{N}{N}$ \\
\hline${ }_{\dot{m}}^{\overline{0}}$ & $\underset{\text { iे }}{\overrightarrow{0}}$ & $\begin{array}{l}\text { \& } \\
\text { i }\end{array}$ & $\begin{array}{l}\text { o } \\
\text { in }\end{array}$ & $\begin{array}{l}\text { స్ } \\
\text { ஸे }\end{array}$ & $\begin{array}{l}N \\
\text { in }\end{array}$ & $\begin{array}{l}\text { N } \\
\text {. }\end{array}$ & $\begin{array}{l}\stackrel{\infty}{\sim} \\
\text { i. }\end{array}$ & $\begin{array}{l}\text { Bn } \\
\text { in }\end{array}$ & $\begin{array}{l}\text { 吕 } \\
\text { ஸे }\end{array}$ & $\begin{array}{l}\mathscr{D} \\
\text { i }\end{array}$ & $\begin{array}{l}\infty \\
\infty \\
\text { N }\end{array}$ & $\begin{array}{l}\infty \\
\infty \\
\text { ஸे }\end{array}$ & $\underset{\infty}{\mathscr{0}}$ & $\begin{array}{l}\text { 20 } \\
\text { is }\end{array}$ \\
\hline ธ్ & స్. & $\begin{array}{l}\text { జ్ } \\
\text { ๓ }\end{array}$ & $\begin{array}{l}\hat{\omega} \\
\ddot{\infty}\end{array}$ & $\begin{array}{l}200 \\
\text { in }\end{array}$ & $\begin{array}{l}\text { R } \\
\text { is }\end{array}$ & 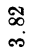 & $\begin{array}{l}\text { m. } \\
\text { i. }\end{array}$ & $\begin{array}{l}\vec{B} \\
\infty\end{array}$ & $\begin{array}{l}\infty \\
\dot{\infty} \\
\dot{\infty}\end{array}$ & $\begin{array}{l}\text { శ్ } \\
\text { లో }\end{array}$ & $\begin{array}{l}20 \\
\text { and }\end{array}$ & $\underset{\text { N }}{\stackrel{N}{N}}$ & $\begin{array}{l}\text { ip } \\
\text { i }\end{array}$ & $\begin{array}{l}\overrightarrow{0} \\
\text { i. }\end{array}$ \\
\hline $\begin{array}{l}\infty \\
\sim \\
\sim\end{array}$ & $\begin{array}{l}R \\
\text { iv }\end{array}$ & $\begin{array}{l}\mathscr{8} . \\
\text { i }\end{array}$ & $\begin{array}{l}\infty \\
\text { in }\end{array}$ & $\begin{array}{l}\infty \\
\text { in }\end{array}$ & $\begin{array}{l}\text { นี } \\
\text { மे }\end{array}$ & $\begin{array}{l}\mathscr{\wp} \\
\text { in }\end{array}$ & $\begin{array}{l}\text { in } \\
\text { in }\end{array}$ & $\begin{array}{l}\text { 昂 } \\
\text { in }\end{array}$ & $\begin{array}{l}\bar{\sigma} . \\
\dot{\infty}\end{array}$ & $\begin{array}{l}\text { :s } \\
\text { is. }\end{array}$ & $\begin{array}{l}\vec{\infty} \\
\text { v }\end{array}$ & $\begin{array}{l}\Delta \vec{b} \\
\text { à }\end{array}$ & $\begin{array}{l}\mathscr{L} \\
\stackrel{\leftrightarrow}{\circ} \\
\text { N }\end{array}$ & స్. \\
\hline ¿े. & $\begin{array}{l}\stackrel{8}{\text { N }} \\
\text {. }\end{array}$ & $\begin{array}{l}\text { to } \\
\text { in }\end{array}$ & $\underset{\infty}{\stackrel{\varpi}{*}}$ & $\underset{\infty}{\stackrel{\sim}{\infty}}$ & $\begin{array}{l}\text { \& } \\
\text { in }\end{array}$ & \&े & $\begin{array}{l}\vec{\infty} . \\
\dot{\infty}\end{array}$ & $\begin{array}{l}180 \\
\ddot{\infty}\end{array}$ & $\begin{array}{l}\infty \\
\ddot{\infty}\end{array}$ & $\begin{array}{l}\infty \\
\infty \\
\boldsymbol{N}\end{array}$ & $\underset{i}{R}$ & $\begin{array}{l}\text { i⿱口内 } \\
\text { ì }\end{array}$ & $\underset{\sim}{\stackrel{\infty}{\sim}}$ & น̊. \\
\hline $\begin{array}{l}\text { ๑ి } \\
\text { ๙ }\end{array}$ & $\stackrel{\Re}{\sim}$ & $\underset{\sim}{\infty}$ & 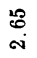 & $\begin{array}{l}\vec{b} \\
\hat{N}\end{array}$ & $\stackrel{20}{\infty}$ & $\begin{array}{l}\text { ¿े } \\
\text { i }\end{array}$ & $\begin{array}{l}\vec{n} \\
\text { in. }\end{array}$ & $\begin{array}{l}8 \\
\text { i }\end{array}$ & $\stackrel{m}{\stackrel{m}{\infty}}$ & $\begin{array}{l}\overrightarrow{\text { N }} \\
\text { in }\end{array}$ & $\stackrel{10}{\frac{10}{10}}$ & $\begin{array}{l}\text { ભొ } \\
\text { iో }\end{array}$ & $\begin{array}{l}\text { शे } \\
\text { ๓ }\end{array}$ & $\vec{F}$ \\
\hline $\begin{array}{l}\vec{\infty} \\
\text { N }\end{array}$ & 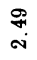 & $\begin{array}{l}\infty \\
\stackrel{\infty}{\infty} \\
\text { i }\end{array}$ & $\begin{array}{l}\infty \\
\infty \\
\text { ஸे }\end{array}$ & $\begin{array}{l}\text { ㅇ } \\
\text { a }\end{array}$ & $\begin{array}{l}\text { \&े } \\
\text { i }\end{array}$ & $\begin{array}{l}\text { ஜึ } \\
\text { ம }\end{array}$ & $\begin{array}{l}\stackrel{2}{12} \\
\text { in }\end{array}$ & $\begin{array}{l}\text { P } \\
\text { in }\end{array}$ & 's & $\begin{array}{l}\mathscr{\varpi} \\
\ddot{\infty}\end{array}$ & $\underset{\sim}{\mathfrak{N}}$ & $\underset{\text { F }}{\mathcal{F}}$ & $\begin{array}{l}\text { के } \\
\text { in }\end{array}$ & 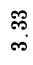 \\
\hline 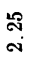 & $\begin{array}{l}\infty \\
\stackrel{\sim}{\sim} \\
\sim\end{array}$ & $\begin{array}{l}\infty \\
\infty \\
\sim\end{array}$ & $\begin{array}{l}\text { Iิ } \\
\text { in }\end{array}$ & ๙ิ & $\begin{array}{l}\infty \\
\stackrel{\infty}{\circ} \\
\text { i }\end{array}$ & $\begin{array}{l}\text { is } \\
\text { in }\end{array}$ & $\begin{array}{l}\bar{b} \\
\text { on }\end{array}$ & $\begin{array}{l}\text { ণิ } \\
\text { ஸ }\end{array}$ & $\frac{\rho}{\text { is. }}$ & $=$ & $\begin{array}{l}\mathscr{0} \\
\text { ஸे }\end{array}$ & $\begin{array}{l}\text { श्: } \\
\text { N }\end{array}$ & $\overrightarrow{\text { ap }}$ & $\underset{N}{N}$ \\
\hline $\begin{array}{l}\stackrel{2}{8} \\
\text { iv }\end{array}$ & $\stackrel{\vec{N}}{\stackrel{N}{*}}$ & $\begin{array}{l}8 \\
\text { N }\end{array}$ & $\begin{array}{l}8 \\
\text { N }\end{array}$ & $\begin{array}{l}\text { P } \\
\text { N }\end{array}$ & $\underset{\sim}{\mathbb{N}}$ & $\begin{array}{l}\text { \& } \\
\text { ix }\end{array}$ & $\stackrel{i}{i}$ & $\stackrel{\Re}{\stackrel{n}{\infty}}$ & $\stackrel{\circ}{\stackrel{0}{\infty}}$ & $\underset{\text { N }}{\text { N }}$ & $\begin{array}{l}\stackrel{\Re}{N} \\
\text { N }\end{array}$ & $\underset{\text { N }}{\stackrel{\sigma}{2}}$ & 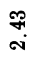 & $\frac{18}{N}$ \\
\hline $\begin{array}{l}\text { đ్ } \\
\text { đิ }\end{array}$ & $\begin{array}{l}\mathscr{B} \\
\text { N }\end{array}$ & $\begin{array}{l}\text { นึ. } \\
\text { ํ. }\end{array}$ & $\begin{array}{l}\infty \\
\text { a }\end{array}$ & బ? & $\begin{array}{l}\text { : } \\
\text { m }\end{array}$ & $\begin{array}{l}\& \\
\infty \\
\text { N }\end{array}$ & 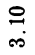 & $\stackrel{\stackrel{p}{\sim}}{\text { N }}$ & $\begin{array}{l}\text { \& } \\
\text { N }\end{array}$ & $\underset{\text { i }}{Z}$ & $\stackrel{8}{\text { is }}$ & $\begin{array}{l}R \\
\text { ov }\end{array}$ & $\begin{array}{l}\infty \\
\stackrel{\sim}{\infty}\end{array}$ & $\begin{array}{l}\hat{\infty} \\
\text { i }\end{array}$ \\
\hline$\stackrel{g}{\stackrel{9}{\infty}}$ & $\begin{array}{l}\vec{\sigma} \\
\stackrel{N}{*}\end{array}$ & $\begin{array}{l}\text { ô } \\
\text { in }\end{array}$ & $\begin{array}{l}8 \\
\text { in }\end{array}$ & $\begin{array}{l}\infty \\
\Leftrightarrow \\
\sim\end{array}$ & $\begin{array}{l}\infty \\
\text { in. }\end{array}$ & $\begin{array}{l}\text { Dे } \\
\text { in }\end{array}$ & $\begin{array}{l}8 \\
\text { in. }\end{array}$ & $\begin{array}{l}\text { శ్ } \\
\text { ஸे }\end{array}$ & $\begin{array}{l}\text { I. } \\
\text { in }\end{array}$ & $\begin{array}{l}\text { ণి } \\
\text { iv }\end{array}$ & $\hat{\sim}$ & $\begin{array}{l}\stackrel{\infty}{\leftrightarrow} \\
\stackrel{N}{N}\end{array}$ & $\underset{\infty}{\infty}$ & $\begin{array}{l}: \\
\ddot{\infty}\end{array}$ \\
\hline $\begin{array}{l}\infty \\
\stackrel{\infty}{\sim} \\
\sim\end{array}$ & 苚 & $\begin{array}{l}\text { ¿゙ } \\
\text { ơ }\end{array}$ & $\stackrel{\oplus}{\infty}$ & $\underset{\text { N }}{\text { i }}$ & ने & $\begin{array}{l}\text { ฉి } \\
\text { ๙ิ }\end{array}$ & $\begin{array}{l}8 \\
\text { i. }\end{array}$ & $\begin{array}{l}\infty \\
\dot{\infty}\end{array}$ & $\begin{array}{l}\text { I } \\
\text { m. }\end{array}$ & $\begin{array}{l}\overrightarrow{0} . \\
\dot{\infty}\end{array}$ & 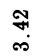 & $\begin{array}{l}\infty \\
\infty \\
\infty\end{array}$ & $\underset{\mathbb{N}}{\mathbb{N}}$ & $\stackrel{?}{\stackrel{?}{\infty}}$ \\
\hline
\end{tabular}




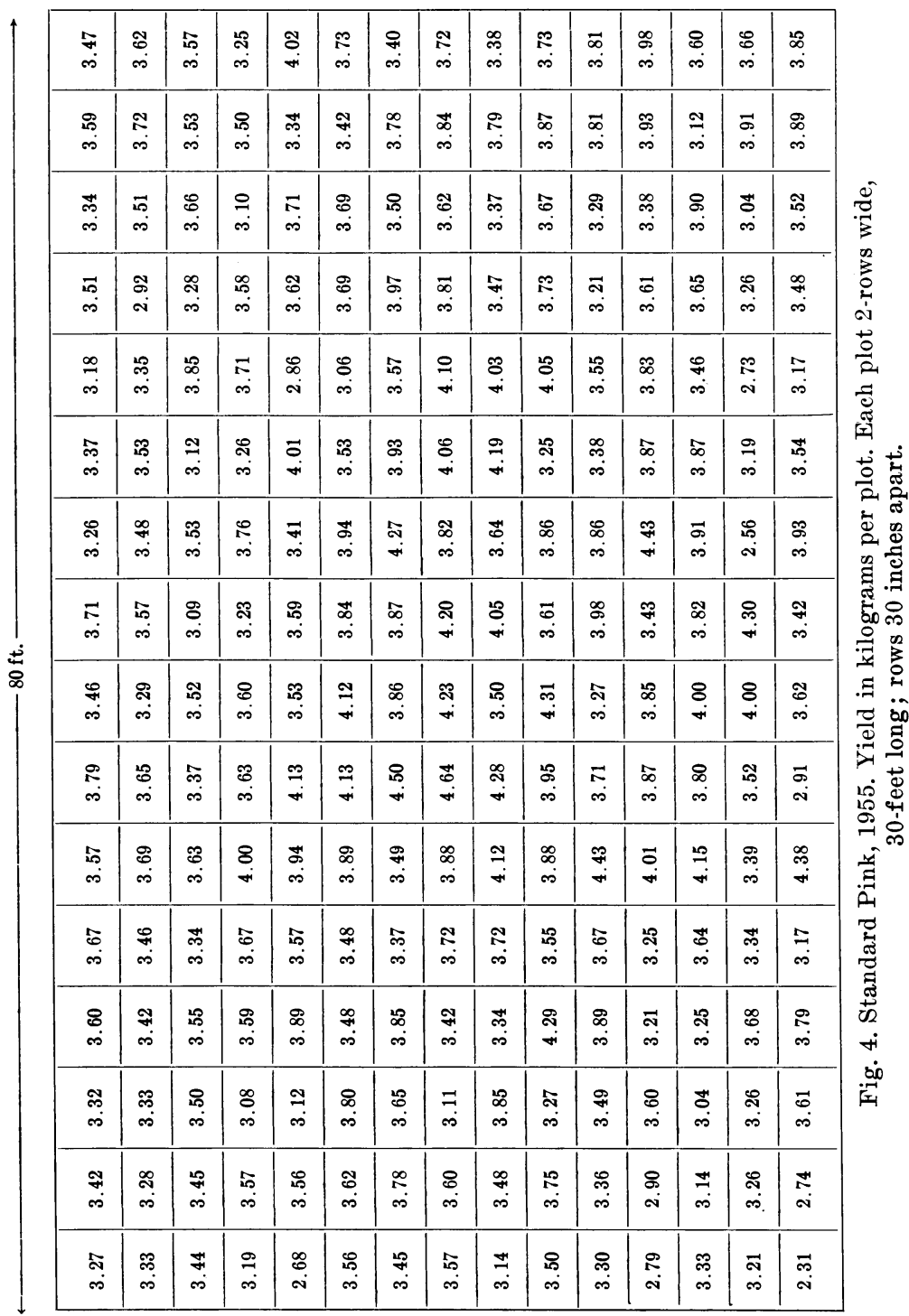




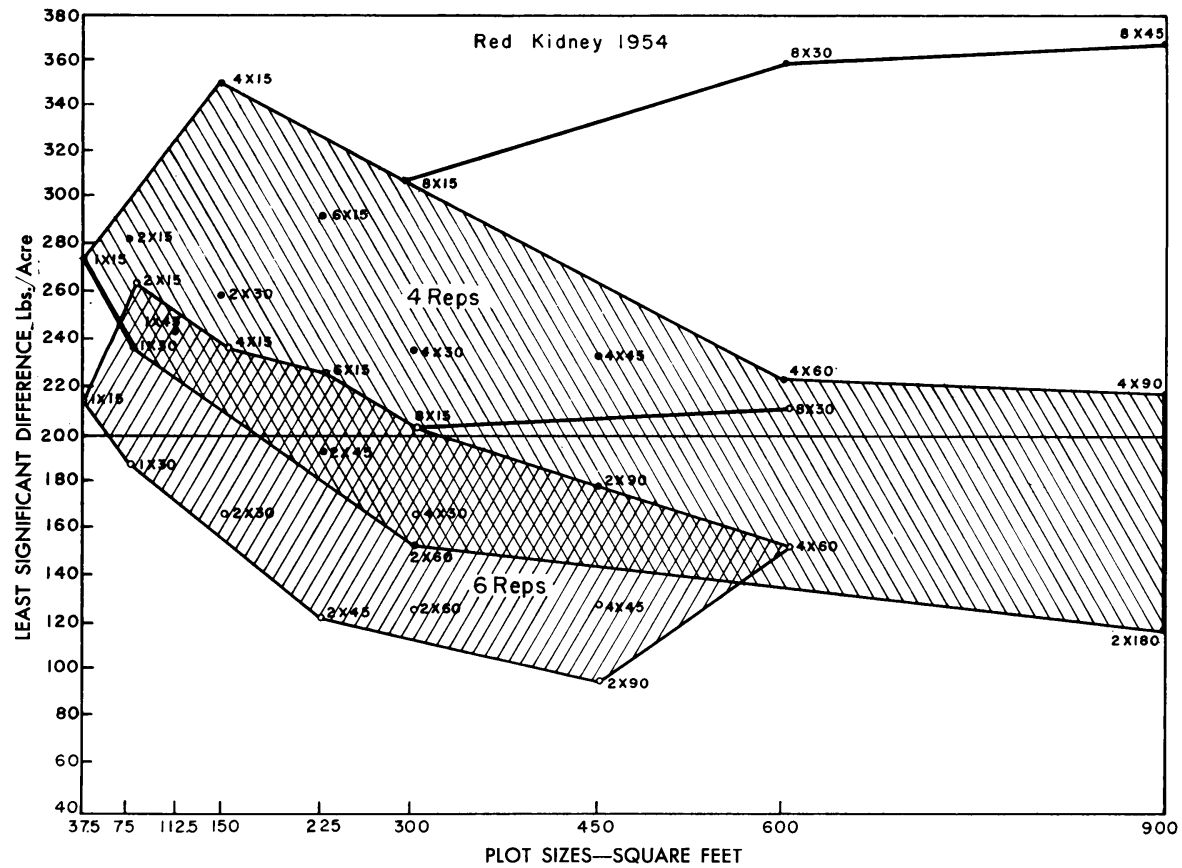

Fig. 5. Least significant differences for various plot sizes of Red Kidney beans in 1954 with 4 and 6 replications.

TABLE 1

LEAST SIGNIFICANT DIFFERENCES OF PLOT WIDTHS AND LENGTHS WITH 4 AND 6 REPLICATIONS

Red Kidney, 1954

\begin{tabular}{|c|c|c|c|c|c|c|c|}
\hline \multirow{2}{*}{$\begin{array}{c}\text { Plot widths } \\
\text { (rows) }\end{array}$} & \multicolumn{5}{|c|}{ Plot length, in feet } & \multirow{2}{*}{ Average } & \multirow{2}{*}{$\begin{array}{c}\text { Regression } \\
\text { per unit area }\end{array}$} \\
\hline & 15 & 30 & 45 & 60 & 90 & & \\
\hline & \multicolumn{7}{|c|}{4 Replications } \\
\hline $1, \ldots \ldots \ldots, \ldots, \ldots$, & 274 & 233 & 242 & $\ldots$ & $\ldots$ & 249 & -16.00 \\
\hline $2 \ldots \ldots \ldots \ldots \ldots \ldots \ldots \ldots$ & 282 & 279 & 191 & 150 & 177 & 216 & -12.75 \\
\hline $4 \ldots \ldots \ldots \ldots \ldots \ldots \ldots \ldots$ & 329 & 236 & 233 & 216 & 216 & 246 & -4.64 \\
\hline $6 \ldots \ldots \ldots \ldots \ldots \ldots \ldots \ldots$ & 294 & 270 & $\ldots$ & $\ldots$ & $\ldots$ & 282 & -4.00 \\
\hline $8, \ldots \ldots \ldots \ldots \ldots \ldots \ldots \ldots \ldots \ldots$ & 307 & 360 & 365 & $\ldots$ & $\ldots$ & 344 & +3.63 \\
\hline$----<----$ & --- & ---- & $--\ldots$ & ---- & $-\cdots--$ & ---1 & ---- \\
\hline \multirow[t]{2}{*}{ Average $\ldots \ldots \ldots \ldots \ldots$} & 297 & 276 & 258 & 183 & 197 & 259 & -0.43 \\
\hline & \multicolumn{7}{|c|}{6 Replications } \\
\hline $1 \ldots \ldots \ldots \ldots \ldots \ldots \ldots \ldots \ldots$ & 213 & 189 & $\ldots$ & $\ldots$ & $\ldots$ & 201 & -24.00 \\
\hline $2 \ldots \ldots \ldots \ldots \ldots \ldots \ldots \ldots$ & 263 & 166 & 126 & $\ldots$ & $\ldots$ & 185 & -34.25 \\
\hline $4 \ldots \ldots \ldots \ldots \ldots \ldots \ldots \ldots \ldots$ & 237 & 169 & 140 & $\cdots$ & $\ldots$ & 182 & -2.02 \\
\hline $8 \ldots \ldots \ldots \ldots \ldots \ldots \ldots \ldots \ldots$ & 205 & 215 & $\ldots$ & $\ldots$ & $\ldots$ & 210 & +1.25 \\
\hline$-\cdots--\cdots$ & $--\cdots$ & $---\cdots$ & $-\ldots-$ & $-\ldots$ & ---- & $-\cdots$ & ---- \\
\hline Average $\ldots \ldots \ldots \ldots \ldots \ldots$ & 230 & 185 & 133 & $\ldots$ & $\ldots$ & 192 & -4.04 \\
\hline
\end{tabular}




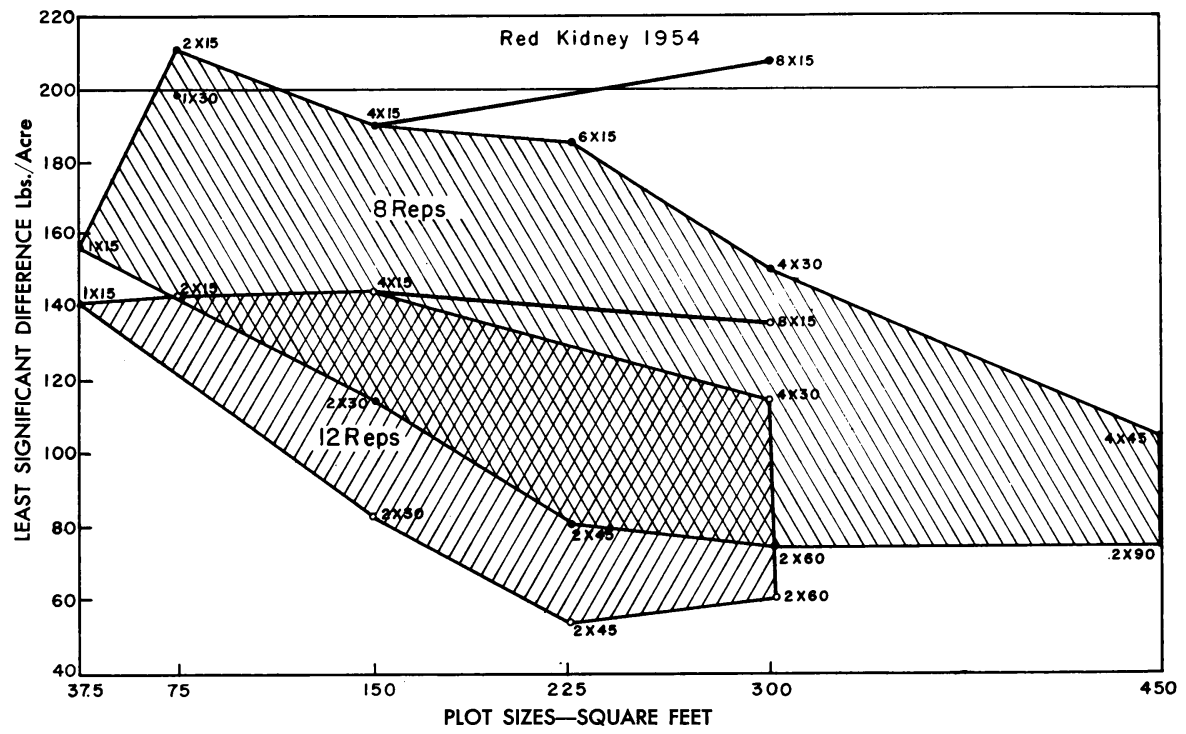

Fig. 6. Least significant differences for various plot sizes of Red Kidney beans in 1954 with 8 and 12 replications.

TABLE 2

LEAST SIGNIFICANT DIFFERENCES OF PLOT WIDTHS AND LENGTHS FOR 4 AND 6 REPLICATIONS

Pinks, 1954

\begin{tabular}{|c|c|c|c|c|c|c|c|}
\hline \multirow{2}{*}{$\begin{array}{l}\text { Plot widths } \\
\text { (rows) }\end{array}$} & \multicolumn{5}{|c|}{ Plot length, in feet } & \multirow{2}{*}{ Average } & \multirow{2}{*}{$\begin{array}{l}\text { Regression } \\
\text { per unit area }\end{array}$} \\
\hline & 15 & 30 & 45 & 60 & 90 & & \\
\hline & \multicolumn{7}{|c|}{4 Replications } \\
\hline 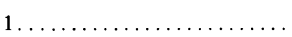 & 381 & 347 & 266 & $\ldots$ & $\ldots$ & 331 & -57.50 \\
\hline $2 \ldots \ldots \ldots \ldots \ldots \ldots \ldots \ldots$ & 295 & 262 & 352 & 373 & 341 & 325 & +7.40 \\
\hline $4 \ldots \ldots \ldots \ldots \ldots \ldots \ldots$ & 225 & 265 & 194 & 184 & 213 & 216 & -1.83 \\
\hline $6 \ldots \ldots \ldots \ldots \ldots \ldots \ldots \ldots$ & 240 & 236 & $\ldots$ & $\ldots$ & $\ldots$ & 238 & -0.67 \\
\hline $8 \ldots \ldots \ldots \ldots \ldots \ldots \ldots$ & 233 & 235 & 146 & $\ldots$ & $\ldots$ & 205 & -5.44 \\
\hline$-----\cdots$ & --- & ---1 & ---1 & $-\ldots$ & $---\cdots$ & $---\cdots$ & $---\cdots$ \\
\hline \multirow{2}{*}{ Average $\ldots \ldots \ldots \ldots \ldots$} & 275 & 269 & 240 & 279 & 277 & 260 & -6.51 \\
\hline & \multicolumn{7}{|c|}{6 Replications } \\
\hline $1 \ldots \ldots \ldots \ldots \ldots \ldots \ldots \ldots$ & 249 & 291 & $\ldots$ & $\ldots$ & $\ldots$ & 270 & +42.00 \\
\hline $2 \ldots \ldots \ldots \ldots \ldots \ldots \ldots \ldots$ & 216 & 186 & 304 & 248 & $\ldots$ & 238 & +10.70 \\
\hline 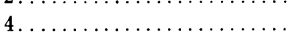 & 169 & 159 & 182 & 136 & $\cdots$ & 157 & -1.90 \\
\hline $8 \ldots \ldots \ldots \ldots \ldots \ldots \ldots \ldots$ & 137 & 111 & $\ldots$ & $\ldots$ & $\ldots$ & 124 & -3.50 \\
\hline$-\cdots-\cdots$ & ---- & ---- & --- & ---- & --- & --- & $---\cdots$ \\
\hline Average $\ldots \ldots \ldots \ldots \ldots$ & 193 & 187 & 233 & 192 & $\ldots$ & 197 & -8.16 \\
\hline
\end{tabular}




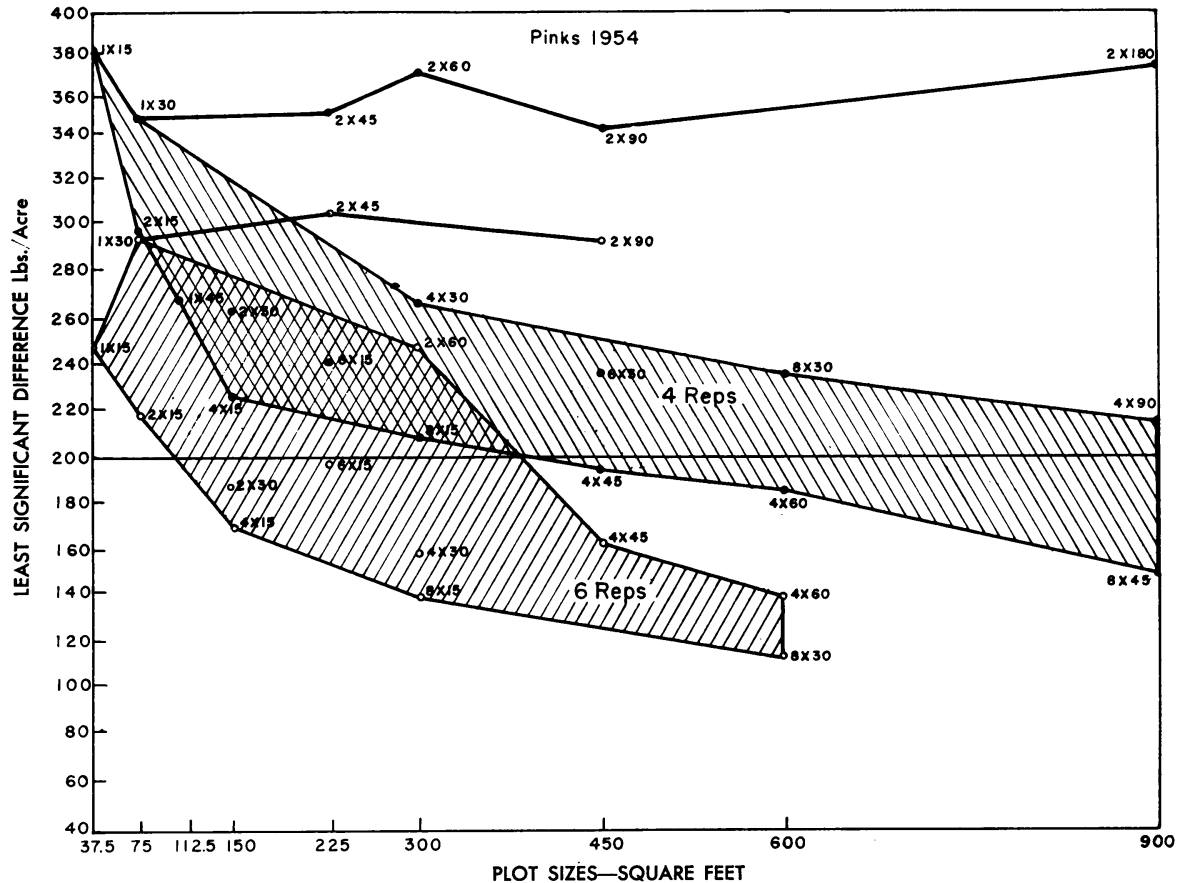

Fig. 7. Least significant differences for various plot sizes of Pink beans in 1954 with 4 and 6 replications.

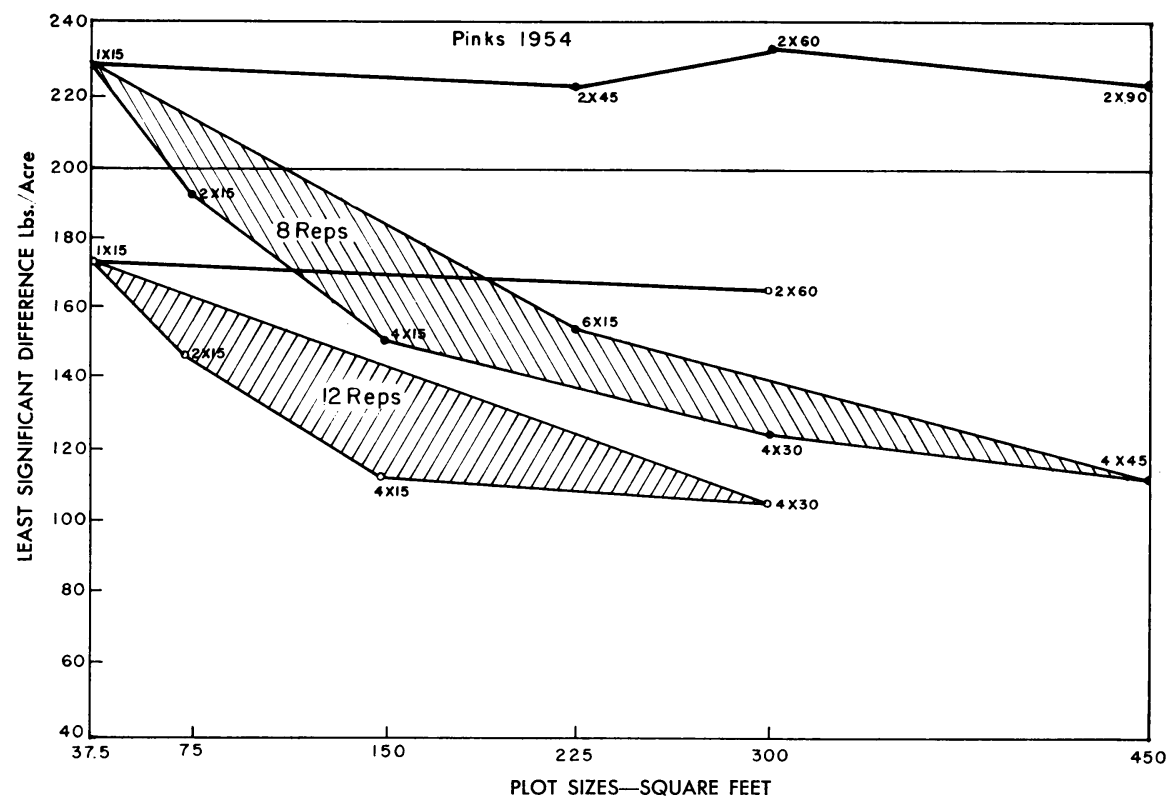

Fig. 8. Least significant differences for various plot sizes of Pink beans in 1954 with 8 and 12 replications. 
the plot sizes (some of which are not shown in table 1) with 4 replications was 261 pounds and for 6 replications 189 pounds. This difference is significant at the per cent level.

\section{Pinks, 1954}

The distribution of LSD's for different plot sizes is shown for 4 and 6 replications in figure 7 and for 8 and 12 replications in figure 8. In table 2 the least significant differences are summarized for 18 plot sizes with 4 replications and 12 plot sizes with 6 replications. The average LSD for 4 replications was

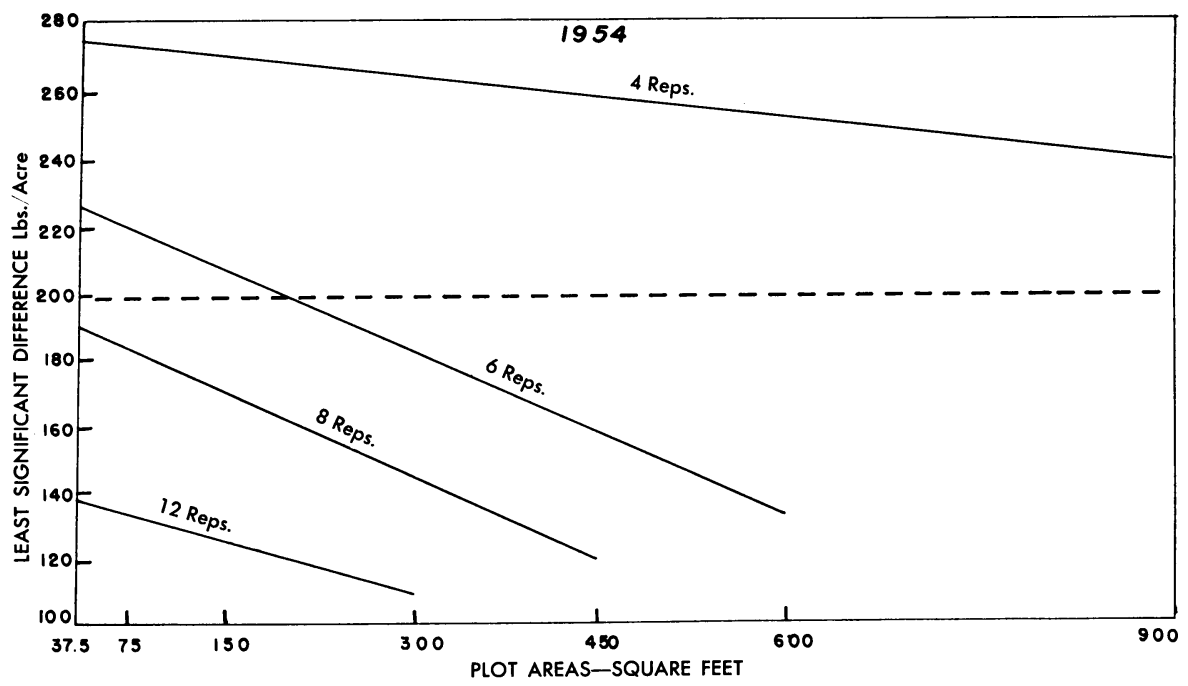

Fig. 9. Regression lines of least significant differences for 4, 6, 8, and 12 replications. Combined data from both Red Kidney and Pink bean plots, 1954.

260 pounds and for 6 replications, 197. The 2-row plots had high LSD's at all lengths, as shown in figures 7 and 8 and table 2 . The calculated regression lines of the LSD's showed that the 2-row plots increased 7.40 pounds per unit area with 4 replications and 10.70 pounds with 6 . Since the 2-row plots were not at the extremes of plot sizes their effect on the total was not as great as in the case of Red Kidney. The regression per unit area of all plots with 4 replications was -6.51 pounds and for 6 replications -8.16 pounds. Analyses of variance were calculated for all plots in 1954 with $4,6,8$, and 12 replications. These calculations did not show a significant difference between varieties. Therefore, 4 regression lines were calculated from all the LSD's of both varieties for all plot sizes tested. These lines are shown in figure 9. They indicate that 4 replications are not sufficient to obtain least significant differences of 200 pounds per acre. This precision was reached at about 200 square feet for 6 replications and 8 and 12 replications were below the 200-pound level with the smallest plot size used.

The difference between the wide and narrow plots in the two varieties in 1954 made it advisable to repeat the experiments on a larger scale in 1955 to see if these differences were due to varietal or to soil variability. It was felt 
that enough information was available from small plots but more was desirable from larger plots. Therefore in 1955 the primary plots were 2-rows wide and 30 -feet long, or 150 square feet-4 times as large as the unit plot sizes in 1954. In each variety 240 plots were harvested, 16-plots wide and 15-plots deep. The yields of these primary plots are shown in figures 3 and 4 . The same procedure was used to set up the randomized plots. Only 4 and 6 replications were studied. The plot sizes studied were all combinations of 2-, 4-, 6-, and 8-rows wide and 30-, 60-, 90-, 120-, and 150-feet long.

\section{Red Kidney, 1955}

The distributions of the LSD's for 20 plot sizes with 4 and 6 replications are shown for Red Kidney in figure 10. These are summarized in table 3. The average LSD for 4 replications was 251 and for 6 replications 176 pounds per acre. This difference is significant at the 1 per cent level.

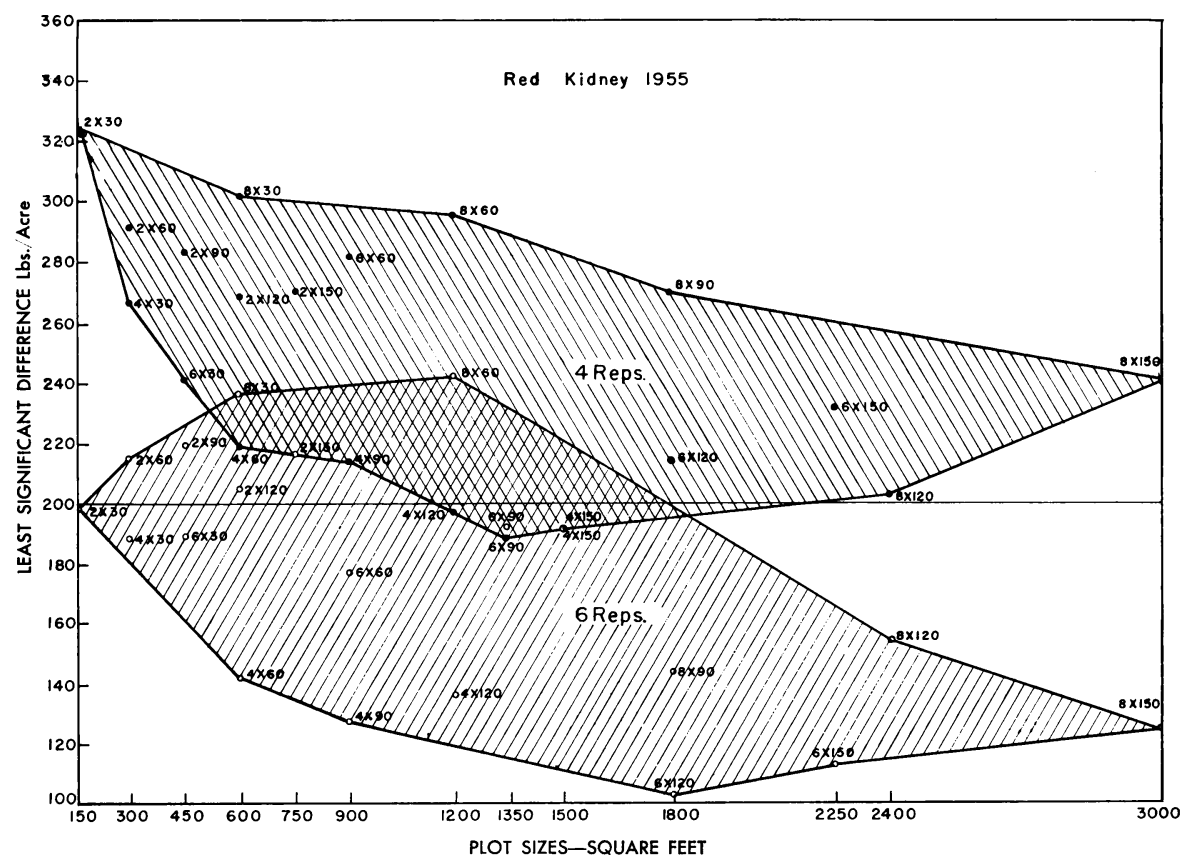

Fig. 10. Least significant differences for various plot sizes of Red Kidney beans in 1955 with 4 and 6 replications.

From the data in table 3, regression lines were calculated for each of the 4-plot widths with 4 and 6 replications. With one exception increases of plot length resulted in decreases in the LSD's. This exception was the 2-row plots with 6 replications. In this case the regression line increased 2.80 pounds per unit area. This is the reverse of the 1954 results where the wide plots showed an increase in LSD's with increasing plot lengths. For all plots with 4 replications the regression was -3.94 pounds per unit area and for 6 replications, -4.97 pounds. 
TABLE 3

LEAST SIGNIFICANT DIFFERENCES OF 20 DIFFERENT PLOT SIZES FOR 4 AND 6 REPLICATIONS

Red Kidney, 1955

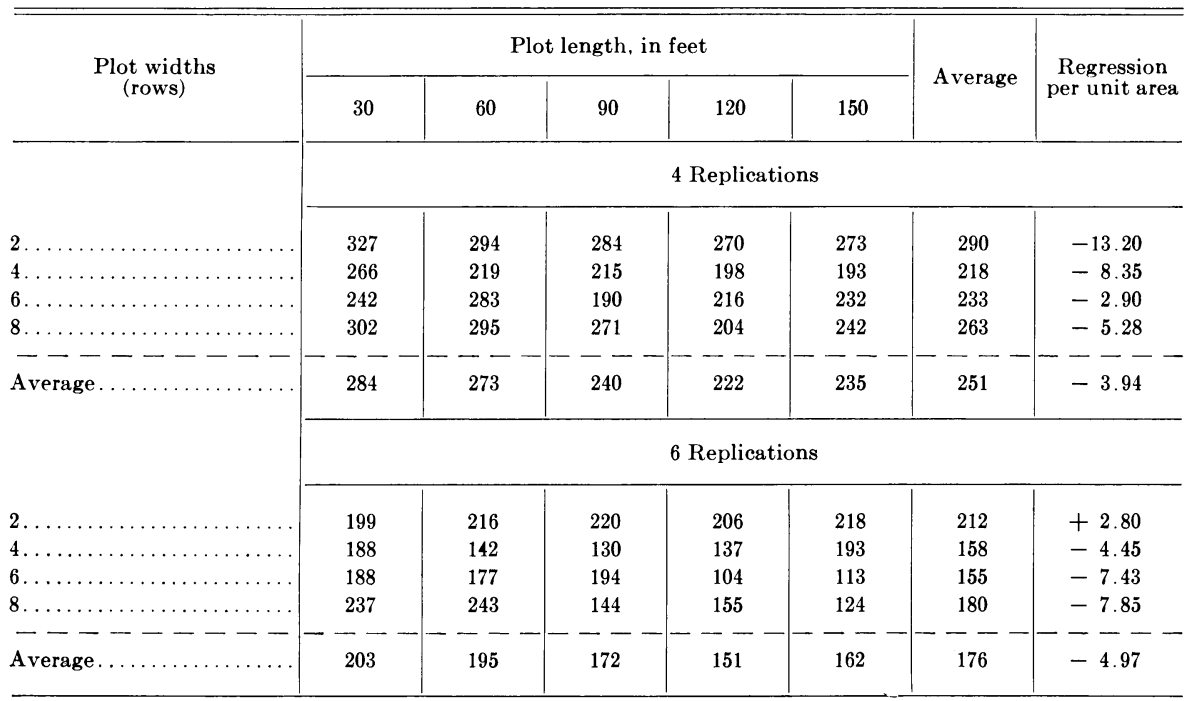

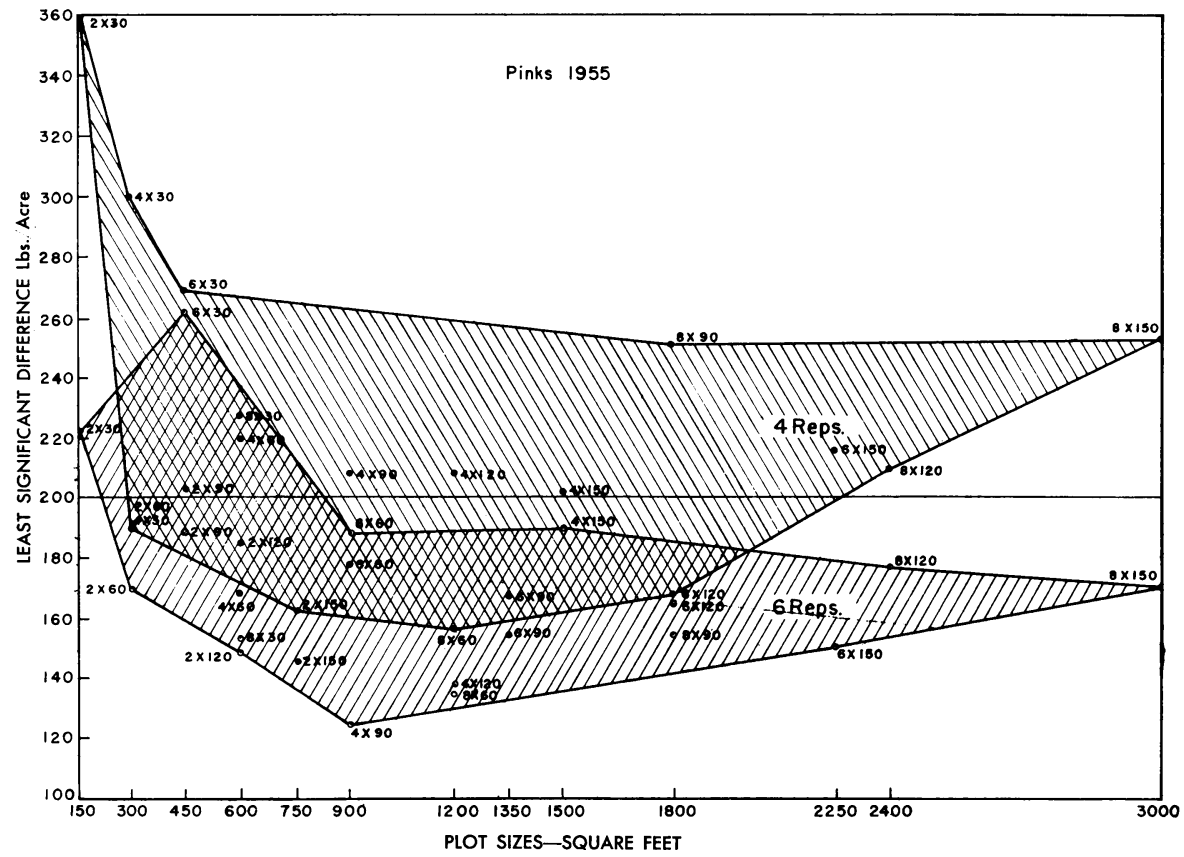

Fig. 11. Least significant differences for various plot sizes of Pink beans in 1955 with 4 and 6 replications. 


\section{Pinks, 1955}

The distribution of the LSD's for 20 plot sizes with 4 and 6 replications is shown for the Pink bean plots in figure 11. These are summarized in table 4. The average LSD for 4 replications was 217 pounds per acre and for 6 replications 171 pounds. This difference is significant at the 1 per cent level.

Regression lines were calculated for each of the plot widths shown in

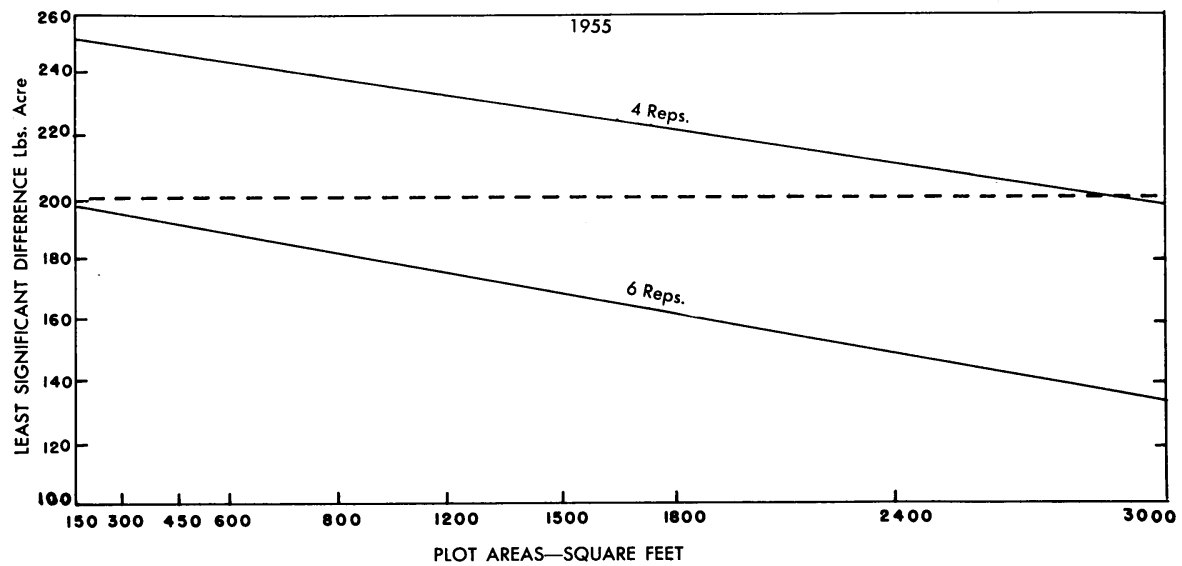

Fig. 12. Regression lines of least significant differences for 4 and 6 replications. Combined data from both Red Kidney and Pink bean plots, 1954 and 1955.

TABLE 4

LEAST SIGNIFICANT DIFFERENCES OF DIFFERENT PLOT SIZES FOR 4 AND 6 REPLICATIONS

Pinks, 1955

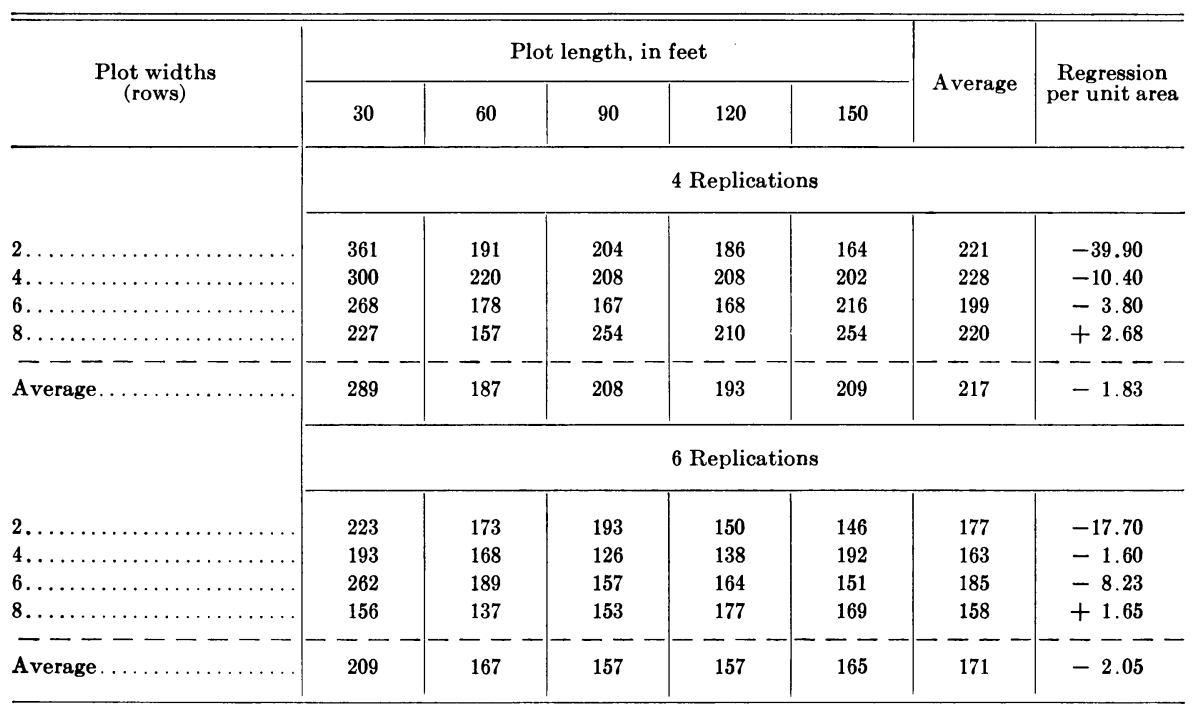


table 4 . With both the 4 and 6 replications the 2-, 4-, and 6-row plots showed negative regressions. But in the 8-row plots there was an increase of 2.68 pounds per unit for 4 replications and 1.65 pounds for 6 replications. This is a reversal of the 1954 results when the LSD's of the 2-row plots increased. The regression line calculated from all plots with 4 replications was -1.83 pounds per unit area and for 6 replications it was -2.05 pounds. The data from both varieties were combined in an analysis of variance. Differences between varieties were not significant for either the 4 or 6 replication experiments. Therefore, all the data were used to calculate the regression line for 1955, shown in figure 12. As in the 1954 results these lines indicate that 4 replications are not sufficient to get LSD's down to 200 pounds per acre until the plot sizes reach nearly 3,000 square feet. The 6 replications were below the figure with the smallest plot size of 150 square feet.

An analysis was made of the LSD's in all plot sizes that were tested with 4 replications in both years. There were only five: $150,300,450,600$, and 900 square feet. In this analysis the mean squares for varieties, plot sizes, and years were calculated as well as the interactions of varieties $\times$ sizes, varieties $\times$ years, and sizes $\times$ years. The only significant $F$ value obtained was between years and it was significant at the 5 per cent level. None of the interactions was significant.

The same analysis was made of the LSD's with 6 replications. Only 4 sizes were available as LSD's were not calculated for plots larger than 600 square feet in 1954. In this analysis no significant $F$ values were found for varieties, years, or sizes or any of the interactions. It would therefore seem that combining all the data from all plot sizes, varieties and years would be a statistically sound procedure. Regression lines were calculated from all the data on both varieties, both years for 4 and 6 replications. These lines are shown in figure 13. It is apparent from these regression lines that 4 randomized replications are not sufficient to reduce the least significant differences to 200 pounds per acre. On the other hand, 6 replications were sufficient to get this precision.

\section{Narrow vs. Wide Plots}

In order to test differences in plot shape, LSD's were assembled in pairs in which plots of the same area but varying in dimensions were compared. The results are shown in table 5 . The 1954 Red Kidney plots with both 4 and 6 replications showed that the narrow plots were more efficient than were the wide plots, with significance at the 1 per cent level. In the 1954 Pink plots the exact reverse was obtained. These contradictory results were caused by the differences between the 2-row and 8-row plots already mentioned. There was a slight but insignificant difference in favor of the narrow plots in both varieties in 1955 for 4 as well as 6 replications. Combining the two years' results for Red Kidney a significant advantage was shown for narrow plots. In case of Pinks the slight advantage of the wide plots was not significant. Other combinations of the data as shown in table 5 were made. The only one which was significant was all comparisons in 1955 which showed an advantage of 26 pounds per acre for the narrow plots-significant at the 5 per cent level. However, when all the data were combined from 74 pairs of comparisons the 


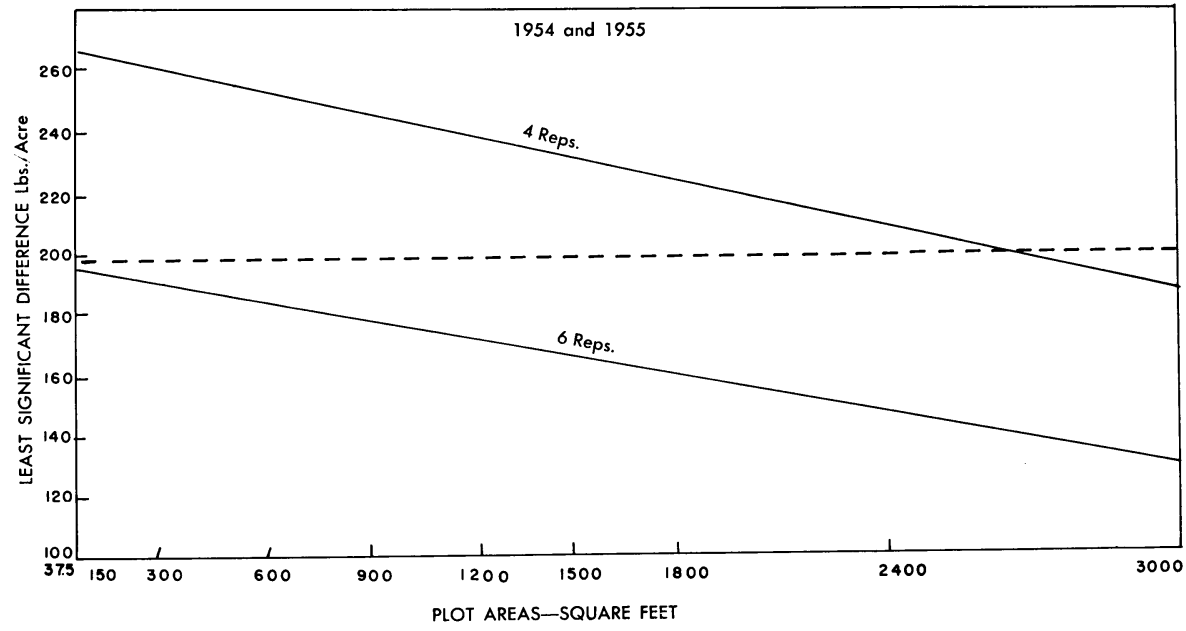

Fig. 13. Regression lines of least significant differences for 4 and 6 replications. Combined data from both Red Kidney and Pink bean plots, 1954 and 1955.

difference in the LSD's was only 13 pounds per acre which was not statistically significant. When the aberrant 8-row plots of Red Kidney and 2-row plots of Pinks of 1954 were eliminated, the remaining 50 comparisons gave a difference of 33 pounds in favor of the narrow plots. This is significant at the 1 per cent level. But in order to get this result some dubious eliminations of data had to be made.

TABLE 5

LEAST SIGNIFICANT DIFFERENCES FOR NARROW VS. WIDE PLOTS

\begin{tabular}{|c|c|c|c|c|c|c|c|}
\hline \multirow{2}{*}{ Varieties } & \multirow{2}{*}{ Years } & \multirow{2}{*}{$\begin{array}{l}\text { Number } \\
\text { replica- } \\
\text { tions }\end{array}$} & \multirow{2}{*}{$\begin{array}{c}\text { Number } \\
\text { compari- } \\
\text { sons }\end{array}$} & \multicolumn{2}{|c|}{ Average LSD } & \multirow{2}{*}{$\begin{array}{l}\text { Differ- } \\
\text { ence }\end{array}$} & \multirow{2}{*}{$\begin{array}{c}\text { F value } \\
\text { between } \\
\text { plot widths }\end{array}$} \\
\hline & & & & $\begin{array}{c}\text { Narrow } \\
\text { plots }\end{array}$ & $\begin{array}{l}\text { Wide } \\
\text { plots }\end{array}$ & & \\
\hline \multirow[t]{2}{*}{ Red Kidney . } & 1954 & 4 & 13 & 192 & 295 & 103 & $26.92^{*}$ \\
\hline & & 6 & 8 & 144 & 208 & 64 & $66.64^{*}$ \\
\hline \multirow[t]{2}{*}{ Pinks... } & 1954 & 4 & 13 & 308 & 223 & -85 & $19.97^{*}$ \\
\hline & & 6 & 8 & 233 & 161 & -72 & $20.48^{*}$ \\
\hline \multirow[t]{2}{*}{ Red Kidney. } & 1955 & 4 & 8 & 246 & 273 & 27 & 1.64 \\
\hline & & 6 & 8 & 179 & 204 & 25 & 2.53 \\
\hline \multirow[t]{2}{*}{ Pinks. . } & 1955 & 4 & 8 & 196 & 229 & 33 & 2.78 \\
\hline & & 6 & 8 & 158 & 177 & 19 & 2.91 \\
\hline Red Kidney ..... & both & both & 37 & 190 & 251 & 61 & $17.87^{*}$ \\
\hline Pinks........... & both & both & 37 & 235 & 201 & -34 & 3.97 \\
\hline Both.... & both & 4 & 42 & 239 & 256 & 17 & 1.26 \\
\hline Both............ & both & 6 & 32 & 179 & 187 & 8 & 0.30 \\
\hline Both............ & 1954 & both & 42 & 228 & 231 & 3 & 3.04 \\
\hline Both............ & 1955 & both & 32 & 195 & 221 & 26 & $4.55 \dagger$ \\
\hline Both............ & both & both & 74 & 213 & 226 & 13 & 1.13 \\
\hline
\end{tabular}

* Significant at the 1 per cent level.

$\dagger$ Significant at the 5 per cent level. 


\section{Precision of LSD Values}

Thirteen cases of LSD calculations were taken from the results of Pinks in 1955. This sample included both 4 and 6 replications of a number of plot sizes. To one of the 4 "varieties" the equivalent of 200 pounds per acre was added to each replication. Then the analysis was run again. This alteration, of course, did not affect the LSD's but it made a marked effect of the $\mathrm{F}$ value for varieties. The results are shown in table 6 . Before the alteration none of the $\mathrm{F}$ values between varieties was significant. When the equivalent of 200 pounds per acre was added to one variety, 5 of the $\mathrm{F}$ values were significant

TABLE 6

THIRTEEN ANALYSES OF VARIANCE OF PINKS, 1955. THE F VALUE IS GIVEN BEFORE AND AFTER 200 POUNDS PER ACRE WERE ADDED TO ONE" "VARIETY"

\begin{tabular}{|c|c|c|c|c|}
\hline \multirow[b]{2}{*}{ Plot sizes } & \multirow{2}{*}{$\begin{array}{l}\text { Number } \\
\text { replications }\end{array}$} & \multirow{2}{*}{ LSD } & \multicolumn{2}{|c|}{$F$ values } \\
\hline & & & $\begin{array}{c}\text { Before } \\
\text { addition }\end{array}$ & $\begin{array}{c}\text { After } \\
\text { addition }\end{array}$ \\
\hline $2 \times 30 \ldots$ & 6 & 233 & 0.60 & 3.11 \\
\hline $4 \times 60 \ldots$ & 6 & 212 & 1.24 & $6.04^{*}$ \\
\hline $4 \times 30 \ldots$ & 6 & 189 & 0.51 & $5.14 \dagger$ \\
\hline $4 \times 60$.. & 6 & 125 & 1.24 & $4.62 \dagger$ \\
\hline $4 \times 120 \ldots$ & 6 & 138 & 2.13 & $5.98^{*}$ \\
\hline $8 \times 60 \ldots$ & 6 & 137 & 0.08 & $5.71^{*}$ \\
\hline $6 \times 120 \ldots$ & 6 & 164 & 1.66 & $19.61^{*}$ \\
\hline $4 \times 30 \ldots \ldots \ldots \ldots$ & 4 & 260 & 0.68 & 3.28 \\
\hline $4 \times 60 \ldots$ & 4 & 265 & 0.57 & 2.79 \\
\hline $4 \times 60 \ldots$ & 4 & 278 & 0.46 & 3.15 \\
\hline $4 \times 120 \ldots$ & 4 & 208 & 0.94 & $4.59 \dagger$ \\
\hline $8 \times 60 \ldots$ & 4 & 157 & 0.58 & $7.87^{*}$ \\
\hline $6 \times 120 \ldots$ & 4 & 168 & 0.69 & $7.34 \dagger$ \\
\hline
\end{tabular}

* Significant at the 1 per cent level.

$\dagger$ Significant at the 5 per cent level.

at the 1 per cent level and 4 were significant at the 5 per cent level. In every case where the LSD was near or below 200 pounds per acre the addition of 200 pounds to one variety made the variety $F$ value significant. Only those with LSD's above 233 pounds were not made significant. This test indicates that the $\mathrm{F}$ value of the varieties is a reliable measure of varietal differences.

There were 450 analyses of variance calculated in the course of these studies. Since the "varieties" were determined by chance it might be possible by chance that one variety was regularly given the highest or lowest yielding plots resulting in significant $F$ values between varieties. There were only 7 cases (1.55 per cent) in which the $F$ values for varieties were significant at the 5 per cent level and only one ( 0.22 per cent) at the 1 per cent level.

In the analyses of variance, $\mathrm{F}$ values were also calculated for significance of difference between the replications. A summary of these is given in table 7 . In both years about $2 / 3$ of the plot analyses showed no significance between replications where there were 4 replications, and about $1 / 2$ where there were 6 replications. In 1954, $1 / 3$ of the plots showed no significant differences 
for 8 replications and $1 / 4$ where 12 replications were used. This indicates a definite relationship between the $\mathrm{F}$ values and number of replications. As the number of replications is increased the precision of detecting differences between them is also increased. Or is this due to increase of soil variability as the plot sizes are increased? This can be partially tested by a comparison of small plots of less than 300 square feet and large plots of over 300 square feet. There were 248 analyses with 4 replications. Of the 125 which were less than 300 square feet 82 or 64 per cent were not significant. In the 123 large plots 79 or 64 per cent were not significant. There were 153 analyses of plots

TABLE 7

SUMMARY OF F VALUES BETWEEN REPLICATIONS. THE VALUES ARE ARRANGED INTO THREE HEADINGS, NOT SIGNIFICANT, SIGNIFICANT AT THE 5 PER CENT LEVEL AND AT THE 1 PER CENT LEVEL FOR VARIOUS NUMBERS OF' REPLICATIONS

\begin{tabular}{|c|c|c|c|c|c|c|}
\hline \multirow{3}{*}{ Year } & \multirow{3}{*}{$\begin{array}{l}\text { Number } \\
\text { replications }\end{array}$} & \multicolumn{4}{|c|}{ Number of $F$ values } & \multirow{3}{*}{ Total } \\
\hline & & \multicolumn{2}{|c|}{ Not significant } & \multicolumn{2}{|c|}{ Significant } & \\
\hline & & Number & Per cent & $\begin{array}{l}5 \text { per cent } \\
\text { level }\end{array}$ & $\begin{array}{l}1 \text { per cent } \\
\text { level }\end{array}$ & \\
\hline \multirow[t]{4}{*}{1954.} & 4 & 106 & 66 & 35 & 19 & 160 \\
\hline & 6 & 39 & 49 & 12 & 28 & 79 \\
\hline & 8 & 10 & 33 & $\mathbf{5}$ & 15 & 30 \\
\hline & 12 & 5 & 26 & 4 & 10 & 19 \\
\hline \multirow[t]{2}{*}{1955 . } & 4 & 55 & 63 & 19 & 14 & 88 \\
\hline & 6 & 38 & 51 & 17 & 19 & 74 \\
\hline Total. & $\ldots \ldots$ & 253 & 56 & 92 & 106 & 450 \\
\hline
\end{tabular}

with 6 replications. Of the 81 small plots, 32 or 39 per cent were not significant and of the 72 large plots 37 or 51 per cent were not significant. These data indicate that increasing plot size alone did not alter the proportion of significant $\mathrm{F}$ values for replications.

\section{Latin Square Arrangement of Plots}

If a large part of the residual variation could be taken out in the analyses of variance the magnitude of the LSD's would be reduced. The Latin Square offers a method of doing this because it removes from the residual error soil variation in two directions. But this results also in a loss of degrees of freedom. Does the reduction of the variation more than compensate for the loss of degrees of freedom? To study this, 13 plots of varying size were chosen ranging in area from 87.5 to 900 square feet. Samples were taken from data on both varieties and both years. The LSD's were compared for four randomized replications with $4 \times 4$ Latin Squares. In this comparison the average LSD for the randomized plots was 271 pounds per acre, while the average LSD of the Latin Square plots was 189. This difference is highly significant. In this comparison, the arrangement of plots in a Latin Square was equivalent to adding 2 replications to a randomized arrangement of plots. 


\section{Comparisons of Efficiency of Different Arrangements of Plots}

It is possible to make some comparisons on the effects of plot size, size of the experimental area, and number of replications by using the yield data from the same area of the field. For this study each of the four experimental fields was sampled.

1. What is the effect of doubling the plot size and simultaneously doubling the experimental area with the number of replications remaining constant?

2 . What is the effect of doubling the number of replications and reducing the plot size simultaneously with the experimental area remaining constant?

3 . What is the effect of doubling the number of replications and simultaneously doubling the experimental area with the plot size remaining constant? The results of these three tests are shown below:

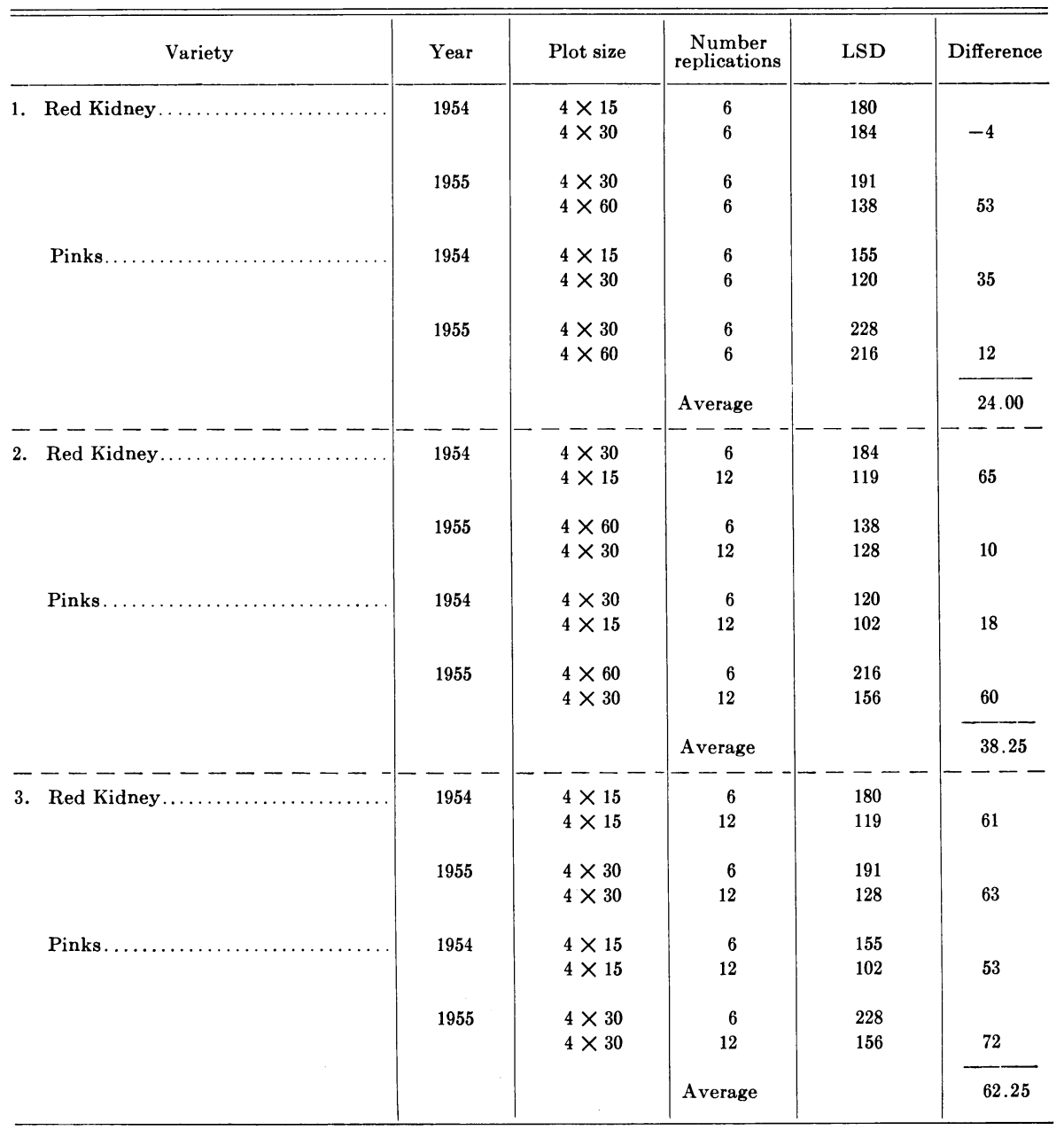


These comparisons indicate that doubling the plot size with the number of replications kept constant was least efficient (case 1). Doubling the number of replications in the same experimental area was a little more efficient (case 2). Doubling the number of replications with plot size remaining constant was most efficient. In fact the advantage was exactly equal to the other two systems combined.

\section{SUMMARY AND CONCLUSIONS}

Uniform nurseries of Red Kidney and Pink beans were grown in 1954 and 1955. In 1954 the unit plot size was 37.5 square feet. In 1955 it was 150 square feet. Wider and longer plots were made by adding adjacent plots laterally and in tandem. Upon these primary plots 4 "varieties" were superimposed. In 1954, 4, 6, 8, and 12 replications were tested, while in 1955 only 4 and 6 . After the yields were assigned by lot to each variety, analysis of variance was made of each experimental area in which the variance between replications and between varieties was subtracted from the total variance. Least significant differences in pounds per acre were calculated from the residual variances. In 1954, 19 plot sizes were tested with 4 replications; 14 with 6 replications; 11 with 8 replications, and 6 with 12 replications. In 1955, 20 plot sizes were tested with 4 and with 6 replications. Regression lines were calculated for the LSD's for all plot sizes tested in both varieties for both years.

The results showed there was a reduction of the LSD's with increasing plot sizes. An ideal LSD of 200 pounds per acre, however, was seldom reached with 4 randomized replications. With 6 replications the 200 -pound level was attained with even small plots less than 100 square feet. With 8 and 12 replications, the LSD's were below 200 pounds per acre with all plot sizes.

In 1954 the 2-row plots of Red Kidney and the 8-row plots of Pinks remained high at all plot lengths. In the tests the following year similar but less extreme results were obtained for 2- and 8-row plots but the varieties were reversed, indicating that the differences between plot widths were not due to varietal characteristics.

There was a slight but not significant advantage of narrow plots over wide plots with the same area.

$\mathrm{F}$ values between replications showed that with 4 replications $2 / 3$ were not significant at the 5 per cent level, with 6 replications about $1 / 2$, with 8 about $1 / 3$, and with 12 about $1 / 4$. Increasing replication numbers improved the precision in detecting significant differences between the replications.

Significant reductions of the LSD's were obtained with 4 replications arranged in a Latin Square over the randomized plots. This was equivalent to the addition of 2 randomized replications.

Comparisons were made with yield data from each of the 4 fields. The effects of changing the number of replications, the area of individual plots, and the experimental area of the field were compared. These comparisons showed that a greater reduction of least significant difference was obtained by simultaneously increasing plot size and experimental area than was attained by either increasing plot size alone or increasing the number of replications in a given experimental area. 
The recommendation from these studies is that if least significant differences of 200 pounds per acre between varieties or treatments are to be attained, 6 replications are necessary if randomized plot arrangements are used. Increasing the replication number from 4 to 6 was more effective than increasing plot sizes. As many as 8 replications were not found necessary to attain this precision.

\section{LITERATURE CITED}

BAKER, G. A., and R. E. BAKER

1953. Strawberry uniformity yield trials. Biometrics $9: 412-21$.

DAY, JAMES W.

1920. The relation of size, shape, and number of replications of plants to probable error in field experimentation. Jour. Amer. Soc. Agron. 12:100-05.

Down, E. E., and J. W. THAYER, JR.

1942. Plot techniques studies with navy beans. Jour. Amer. Soc. Agron. 34:919-23.

Loessell, C. M.

1936. Size of plot and number of replications necessary for varietal trials with white pea beans. Jour. Amer. Soc. Agron. 28:534-48.

Love, H. H.

1943. Experimental methods in agricultural research. University of Puerto Rico Agr. Exp. Sta. Pp. 1-229.

SNEDECOR, GEORGE W.

1956. Statistical methods. 5th ed. Iowa State College Press. 

The journal Uilgardia is published at irregular intervals in volumes of about 600 pages. The number of issues per volume varies.

Subscriptions are not sold. The periodical is sent as published only to libraries, or to institutions in foreign countries having publications to offer in exchange.

You may obtain a single copy of any issue free, as long as the supply lasts; please request by volume and issue number from:

Agricultural Publications

Room 22, Giannini Hall

University of California

Berkeley 4, California

The limit to nonresidents of California is 10 separate issues on a single order. A list of the issues still available will be sent on request. 